\title{
The place of agricultural research in the development of sub-Saharan Africa
}

\author{
Michael Lipton
}

\section{Research: Resources, Policy, Results}

This article is confined to the countries in sub-Saharan Africa (SSA), excluding the Republic of South Africa (RSA). It largely excludes the policy requirements of agricultural research and the statistical evidence [Lipton 1985].

Three general statements can be made. Despite the path-breaking experiences in Asia of (say) the Punjabs, Sonora, and Central Luzon - and despite the African precedent, now 20 years old, of SR-52 hybrid maize - most of SSA now offers smallholders no dramatic, immediately applicable new technology that might, with plausible increases in output/input price ratios, or in person/land ratios, safely and substantially increase the profitability of food farming over large areas. While this is so, the elasticity of total farm output to currently recommended policy changes, including price changes, can seldom be very large. More or better agricultural research (AR) is necessary, but seldom sufficient, to remedy this.

The AR policy issue can be addressed by seeking to explain a paradox. Rates of return to $A R$ have been shown to be very large. By the standards of the developing world, SSA appears to be spending a good deal on AR (and to be supporting it with unusually high levels of extension). ${ }^{1}$ Yet, by those same standards, agricultural growth in SSA, except for a few countries, has been notoriously slow. Moreover, SSA is unlike other parts of the world in that the success of a nation's agriculture does not seem to have been strongly linked to its level or growth-rate of AR outlay or scientist numbers.

There are two explanations. First, there is less AR in most of SSA than there seems to be. Second, even that 'less' is less good at producing output-oriented results

${ }^{1}$ For cvidence that outlay on extension generally increases the return to outlay - especially subsequent outlay - on research, see Evenson and $\mathrm{K}$ islev, 1976. On SSA's exceptionally high extensionresearch ratios, see Oram and Bindlish, 1981: 44, 100; Boyce and Evenson. 1975: 3-13 and especially Pinstrup-Andersen, 1982: 66-7. in SSA than in most other poor countries. Many, probably most, SSA countries are paying for - and getting - much less AR than the crude numbers (dollars, scientific person-years) indicate.

An even more important explanation of the paradox lies in the nature of that research. One group of problems concerns critical mass. There seem to be scale-economies in research-station size, to well above the sizes achieved in most of SSA. ${ }^{2}$ Yet the difficulties of SSA countries, mostly poor and small, in attaining critical mass are aggravated by high turnover; by 'loss' of AR benefits to nearby countries without regional co-ordination; and by dispersion of scientists among stations and programmes.

This last problem arises partly out of efforts to solve a second group of problems, those of relevance of centralised AR to local conditions. Partly, this is due to lack of 'congruence' [Boyce and Evenson, 1975:8398; Judd, Boyce and Evenson, 1983:23-8] between the output-mix and the research-mix, even allowing for different prospects of success in different types of work. Partly, it reflects inadequate integration of economic and social analysis into agricultural research. The overseas orientation of much SSA research cannot help either.

But the main reason why SSA agricultural research has not contributed more to output is the absence of a proper policy framework. This gap explains the truly appalling shortage of basic facts on farm output, especially smallholder food output - and even, to some extent, about farm research. Is 'research policy', then, the key? In one sense, no: little will be achieved by persuading SSA count ries to adopt a blueprint that centralises agricultural research upon a high-powered research institute or interdepartmental committee. In a second sense, again no: overall policy (on food strategies, nutrition and income-distribution, infor-

\footnotetext{
2 There appear, however. to be diseconomies of scale to expansion of a country's total researcher est ablishment: see Boyce and Evenson, 1975: $99-100$.
} 


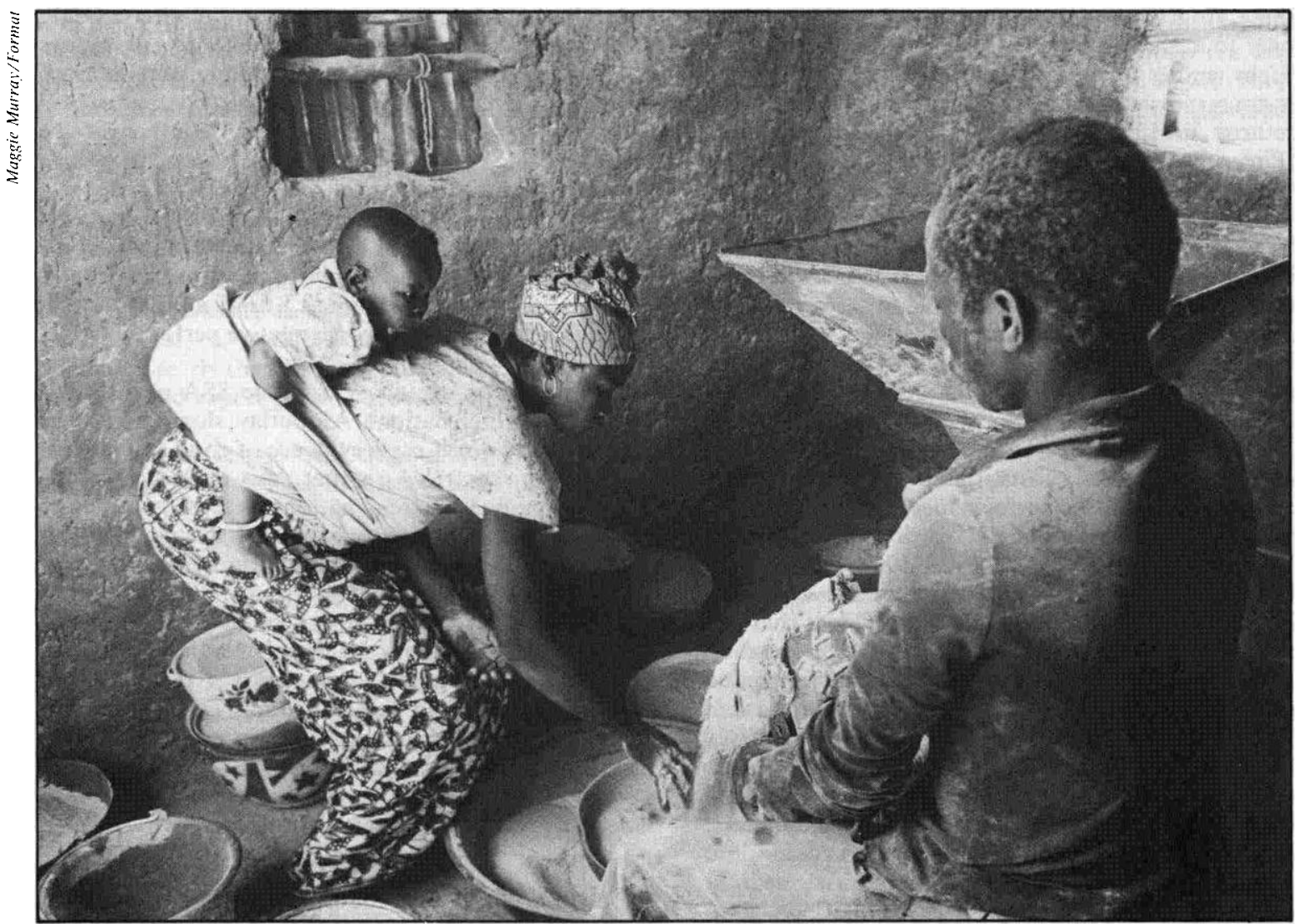

A simple grain mill enhances productivity.

mation systems, labour-intensity, irrigation and water management, and above all agriculture's share of real resources) is required, before research policy can help. Yet, in a final sense, research policy is the key. It is possible to out line research contents, career structures, and priorities that - given adequate real indigenous resources and a roughly feasible agricultural policy -will greatly increase the chances that those resources will achieve the output and distribution goals of the policy.

\section{High AR Spending, Low Output Pay-off}

The size of AR in SSA, compared to agricultural output and even agricultural production, seems to be quite large. In 1974, public-sector agricultural research expenditure was 1.12 per cent of agricultural output in western SSA, 1.63 per cent in eastern SSA, and about 1.45 per cent in southern SSA. ${ }^{3}$ Figures for other developing regions were substantially lower, e.g. 0.31 per cent in South Asia and 0.49 per cent in SE

Ibid, p.46. The last figure includes RSA, but its ratio appears to be closer to 1 per cent than to 1.5 per cent. Hence the ratio for southern SSA proper is even higher than 1.45 per cent
Asia ${ }^{4}$ Comparisons for 1980 are available for only a few LDCs. They show a similarly high-spending performance on SSA research, at each income level.

In 1975, 10 examples of direct cost-benefit analysis, and 11 sources-of-growth studies of national AR were collated. Internal rates of return in the former group ranged from 20 per cent (US poultry) to 60 per cent (Indian sugarcane) and 45-93 per cent (Mexico, various crops). The seven studies from developing countries showed somewhat higher returns than the studies from developed countries, and a parallel study 'estimated marginal internal rates of return of 42 per cent to technologically oriented research in developing countries and 21 per cent in developed countries' [Boyce and Evenson 1975:110, fn.]. However, there was not one study of returns in SSA [ibid::103].

By 1982, 50 such studies - still not one in SSA could be collated. "Average annual rates of return for

\footnotetext{
${ }^{4}$ Boyce and Evenson 1975: 46. Other (generally richer) developing regions: West Asia, 0.83 per cent; North Africa, 0.72 per cent; temperate South America, 1.29 per cent; tropical South America, 1.03 per cent; Central America and Caribbean, 0.71 per cent.
} 
these programmes are slightly less than 50 per cent, only four showing returns of less than 20 per cent.' Eight studies in Asian developing countries showed average returns of 44 per cent, and the 14 quantifiable returns in Latin America averaged 47 per cent [Pinstrup-Andersen 1982:102-4].

Whatever allowances need to be made for bad data, however, we have a paradox. Returns to AR are extremely high, especially in LDCs. Public ${ }^{5}$ research outlay per unit of GDP, of land area, and of agricultura ${ }^{6}$ population was much higher in the $1970 \mathrm{~s}$ in SSA than in South or South-East Asia. Yet agricultural production grew far more slowly for most of SSA than for most of South, and almost all of SE, Asia [World Bank 1984:90,220]. There is no correlation between substantial (or fast-growing) AR and good agricultural performance in SSA, as there is, for example, among India's Districts [Evenson and Kislev; and Oram and Bindlish 1981, Annex 2B]. Moreover, rapid growth of national public-sector AR outlays in SSA - more than tripling as a share of agricultural GDP in West Africa, and more than quintupling in East Africa, in 1959-80 - accompanied sharp deceleration in agricultural growth [Judd $e t$ al., 1983].

Of course, even good AR is not sufficient for growth. This is constrained in SSA by the physical, climatic, trade and policy environments - bad, worsening, and unpredictably fluctuating. The dichotomy 'researchenvironment' cannot be pushed too hard, as good research aims at suitability for the environment. It is, in any case, fairly clear that national agricultural research in much of SSA is not giving value for money. Large outlays are buying modest numbers of scientists, often underqualified, who are producing extremely modest results by world standards.

\section{AR Output/Cost Relationships}

Compared to the low-income South Asian countries (India, Pakistan, Bangladesh, Sri Lanka and Nepal) the six low-income SSA countries with available data for 1980 spent 1.8 times as large a share of (alleged) agricultural GDP on national agricultural research. However, in 1980 they paid 3.2 times as much per scientist-year. Nevertheles, in 1974, SSA obtained only 55 per cent as many 'standardised publications' per scientist-year [Boyce and Evenson 1975:42]. Thus,

${ }^{5}$ The private sector contributes only 3 per cent of agricultural research outlays in developing Asia and Africa [Boyce and Evenson 1975: 77 ]

${ }^{6}$ For example, in the eight 'SSA low-income countries' in Table 1 [Burundi, Kenya, Madagascar, Senegal (sic). Sudan, Tanzania, Togo and Zaire: Oram and Bindlish 1981: 89], the proportion of their total population dependent mainly on agriculture is above 80 per cent, as against some $65-68$ per cent for the low-income SSA region. despite a much larger research effort relative to GDP, the low-income SSA countries with recent figures appear to have obtained barely 30 per cent as much national 'research output', as indicated by standardised publications, per unit of agricultural GDP as did the South Asian countries. ${ }^{7}$ Several specialists, at a recent IFPRI meeting, concurred that the cost of doing a comparable piece of research was at least three times as high in SSA as in South Asia; for low-income countries ' 30 per cent as much research output per unit of agricultural GDP, despite 1.8 times more outlay per unit' suggests an even worse relative performance.

So part of the explanation of the SSA agricultural paradox - high national AR out lay, slow agricultural growth, yet world-scale evidence of good agricultural returns to research - is that most of SSA is getting exceptionally little 'real' national research output per scient ist, and paying heavily for each scientist: and this despite unusually high support from extension, and from international research systems. Since "countries will respond to lower prices of national scientific resources ... the issue of training scientists at low cost in national programs now deserves much greater attention from aid donors' [Judd et al., 1983:47]. Further, so-called 'national AR' in much of SSA despite exceptions, such as Kenya - reflects foreign money, personnel, and intellectual commitment much more than in other developing regions.

\section{Critical Mass and Local Relevance}

Part of the reason why many African governments - as opposed to aid donors - find AR unattractive is the group of problems associated with critical mass. World-wide, countries with below $\$ 400$ of GDP per person in 1974 located 49 per cent of their scientists in experiment stations with over 21 persons; the proportion for better-off countries was 61 per cent [Boyce and Evenson 1975:83]. Poor communications within LDCs make the dispersion of scientists in SSA even more damaging to prospects of achieving a critical mass; so does the fact that, because fewer scientists are highly trained (and because technicians and administrators are scarce), much 'research' time in each station is diverted to technical and administrative duties.

Compared with South Asia, too, the small populations of most SSA countries - together with the fact that a typical such country combines agricultural diversity with linguistic specificity - aggravate the problem even further. Each small country's government must fear, rightly, that its own spending on research will produce mostly unrequited benefits for foreigners. Regional research cooperation has its own costs, both

'Standardised publications are explained, and data given, in Boyce and Evenson 1975: 39-42 and 84-96. 
if nations fall out (as in East Africa) and if free-riding has to be policed. The need to incorporate several disciplines, socioeconomic as well as scientific, if $A R$ is to produce results that benefit smallholders also carries a double burden: it directly raises the required critical mass, and it does so indirectly by imposing, upon researchers, costs of communication to non-specialists.

In these extremely difficult circumstances, there are two possible ways to ease the problem: to reduce staff turnover, or, to reduce the number of research stations. Clearly the second approach has drawbacks, so one would expect great concentration on the first.

One would be disppointed. Kenya is a particularly telling case, because both its AR and its medium-term agricultural growth have been well above the SSA norm [Taylor et al., 1981:v]. Yet 'a USAID report of September 1977 documented the loss of more than 58 research scientists [out of those] working three years earlier' [ibid::77], i.e. about one in four [Boyce and Evenson 1975:174; Judd et al. 1983:60, Oram and Bindlish 1981:89]. This is not due mainly to high expatriate turnover - 'average length of employment in the research division of the Ministry of Agriculture has been $2 \frac{1}{2}$ years for Kenyan personnel and $3 \frac{1}{2}$ years for expatriates' [Taylor et al. 1981:80]. Not all turnover is loss. Some is due to higher training, or transfers to research in the private sector, to (doubtless progressive) farming, or to academic research or management. One does, however, have the uncomfortable suspicion that most turnover is into jobs, often abroad, that do little for AR in SSA. Certainly, much occurs because:

AR scientists and their role in national agricultural development lack recognition [;] the research cadre [is paid less] than people with comparable training and experience in other components of the agricultural sector; [and] the present scheme of service does not provide for scientific career development, recognition and reward for research productivity [Taylor et al., 1981:80-81].

If these career-based causes of high turnover apply even in Kenya, they apply much more forcibly in most of SSA, and are indeed richly documented in various ISNAR reports. Anyway, even where the causes of turnover from public AR are benign and where the recipient sectors benefit greatly, the problem of lost critical mass remains.

Moreover, high turnover among, and out of, publicsector AR stations is damagingly synergistic with the often large number of such stations. If we remain with Kenya, 'research on priority [food] crops is undertaken principally in 42 national and regional sub-stations'; there are also separate commodity research stations for sugar, coffee (four), tea and cotton, and for livestock, animal health and forestry. Many of these stations suffer personnel shortages [ibid.:32-3, 36-7, 54 and Annex 10]:

Resources are considered inadequate in 25 research establishments, and very inadequate in about $15 \ldots$ there are more research stations than can be adequately staffed ... Sub-stations should be managed by [technicians, and scientists concentrated in a few regional and national centres.] It seems wasteful ... to locate one or two young research scientists at [each of many] sub-stations where they are likely to receive little or no guidance and where their chances of being productive are minimal [ibid.:54-5].

Outside Kenya, dispersion among stations is usually even worse. In the Ivory Coast, "la balkanisation actuelle de la recherche agronomique en un nombre élevé d'institutions autonomes, de nationalités, statuts, tutelles et modes de financement' has been very imperfectly remedied by the Ministry of Scientific Research, created in 1971 [von der Osten et al. 1982:20]. In Malawi, apart from the three main stations sharing 60 scientists, another eight minor stations share 12; once again, 'the spending of meagre resources across an inefficient network of stations exacerbates the effects of inadequate resources' [Gilbert et al. 1982:12-13,28].

There is a real case for improving regional representativeness by multiplying research stations; but it tends, in SSA, to reduce an already inadequate 'mass' at each station. An obvious idea is to create national stations located at the borders of two or more agroclimatic zones. Concentration of stations, however, risks even more exclusion of remote (and often very poor) areas, and even more submersion of rural research in urban priorities. Like many issues of research organisation, the issue of 'critical mass' is unlikely to respond to neat, general blueprints, applied rapidly by teams of visiting experts, and claiming to provide general answers to major administrative questions. Much more promisingly:

(a) Simple, unpretentious improvements in Organisation and Methods could increase critical scientific mass via lower turnover and fewer techno-administrative diversions.

(b) Attention to the content of agricultural research could help. Across a great variety of organisational forms in LDCs, some sorts of crop and animal problems seem to respond to research. Concentration of scientists on these research issues would also help to reduce the current dispersion, by increasing the critical scientific 
mass applied to fewer issues [on multiplicity of programmes in Malawi, see Gilbert et al.:vii].

\section{Research/Output Congruence}

Dispersion of scarce scientists among many, distant stations ${ }^{8}$ is a bad way to make AR relevant to the problems of diffused, extensive, diverse agricultutral countries in SSA; but it recognises the relevance problem, just as the concentration proposals recognise the critical-mass problem. Are there better ways to increase the relevance of AR to raising SSA's agricultural welfare, without reducing sustained, collaborative scientific concentration on central issues? One approach is to achieve better 'congruence' between output-mix and research-mix. A second is indigenisation of $A R$ personnel, priorities and purses. A third is to combine socioeconomic with agriculturalscience analysis. A fourth is to switch applied AR into 'farm systems' as well as, or to some extent instead of, individual commodities [Collinson 1982].

The simple rule of congruence, that the ratio of the research expenditure for a commodity to its economic value of . . should be equal for all commodities is based on 'the plasticity of nature' which is over the long term reasonable [Boyce and Evenson 1975:84]. By 'plasticity' Boyce and Evenson mean that, whatever the commodity, "efforts to uncover the secrets of nature' are, more or less, 'equally productive no matter where the effort was directed'. They recognise (a) that a country might research at levels below those indicated by the congruence rate into products heavily researched by 'environmental neighbours'; and (b) that products in price-inelastic demand might justify lower research/output ratios than other products, because benefits would accrue to consumers (as price cuts) rather than to producers, who would be forced to respond to prices by relatively 'costly ... factor adjustment' [ibid.: 118].

The congruence rule - subject to modification (a) above, to commonsense refusal to keep on at products or soils clearly unresponsive for scientifically demonstrable reasons, and to an important distributional caveat - seems a useful rough guideline for SSA. The distributional caveat is that the congruence rule, in assuming 'plasticity of nature' (in respect of marginal as well as average long-run expected productivity of research across commodities), finesses the question of whether extra product values are correctly reflected by relative prices. Many governments' rhetoric, and some governments' practice, would give greater weight, per unit of extra output, to products produced or consumed - preferably both

${ }^{8}$ Apart from the static arithmetic, there is a further drawback, if critical mass depends on continuity in, as well as on numbers at. a station. Each new station represents a new prospect of transfer.
- by very poor people. That would imply abovecongruent research/output ${ }^{9}$ ratios for these products, and below-congruent ratios for others, notably for estate-based export crops. ${ }^{10}$

\section{Research Biases: Domestic and International}

Do SSA commodity compositions of AR - allowing for distribution, for non-responsive commodities, for 'free' foreign reseach, and for the wish not to pass on research benefits to 'price-inelastic demanders' in rich countries - achieve a reasonable degree of relevanceby-congruence? Table 1 reveals not only a bias towards export crops and rich people's crops worldwide, but also a tendency to concentrate research for a crop upon places where it is not a locally-consumed or poor person's product (compare Asian and African data for rice and wheat, much more massconsumption crops in Asia, much more prestige and high-research products in Africa). In general, Africa reveals much greater disproportions, in respect of emphasis upon AR into exported commodities and the products of richer farmers and urban consumers, than does Asia or even Latin America [Judd et al. 1983:27] develop a measure of overall commodity congruence, between output-mix and AR-outlay-mix, for 26 LDCs, including six in SSA. This measure shows that the SSA countries are among the less congruent overall: Ghana ranks 11 th out of 26 , Sudan 14th, Kenya 19th, Uganda 20th, Tanzania 21 st, and Nigeria 23rd. Poor people's crops - cassava, sweet potatoes, maize - everywhere enjoy research/output ratios well below congruence, and rich people's products, especially animal products, ratios much above; but these disparities, in particular, are substantially higher in Africa than in Asia or Latin America [ibid.:24-5]. Despite the much greater reliance of most Asian agricultures on animal draught and integrated farming, it is in SSA that animal husbandry enjoys higher shares of AR [Oram and Bindlish 1981:54]. ${ }^{11}$

The bias in national AR towards export crops [Pinstrup-Anderson 1982:64] and rich people's products, and away from congruence, is especially strong in SSA. Surely, the reasons are political, rather than the results of 'rational' attempts by a neutral state to maximise the yield on research revenues. But the

\footnotetext{
${ }^{9}$ All the Boyce-Evenson, Judd et al., and York et al. data are for gross agricultural product in these estimates. Logically, the BoyceEvenson argument requires net product to be used. In SSA (but not elsewhere) this probably makes little difference.

${ }^{10}$ If such crops are very labour-intensive even on estates. one might nevertheless make a distributional case for high research/output ratios - unless benefits were largely transferred to (price-inelastic) foreign demanders.

"Proportion of research scientists working on animal husbandry, unweighted average: seven South and South East Asian LDCs, 9.3 per cent; seven in SSA, 22.3 per cent; seven in Latin America, 21.1 per cent [Oram and Bindlish 1981].
} 
National AR as a percentage of product value

\begin{tabular}{|c|c|c|c|c|c|c|c|c|c|c|}
\hline Region/zone & Date & Rice & Wheat & Maize & Sorghum & Cassava & $\begin{array}{l}\text { Sweet } \\
\text { Potatoes }\end{array}$ & $\begin{array}{l}\text { Potatoes } \\
\text { (White) }\end{array}$ & $\begin{array}{l}\text { Field } \\
\text { beans }{ }^{2}\end{array}$ & $\begin{array}{l}\text { Chick } \\
\text { peas }\end{array}$ \\
\hline 1. All LDCs & $1971-2^{1}$ & 0.26 & 0.65 & 0.75 & 0.77 & 0.07 & 0.09 & 0.68 & 0.25 & 0.18 \\
\hline 2. Africa & $1972-9$ & 1.05 & 1.30 & 0.44 & $\ldots$ & 0.09 & 0.19 & 0.43 & 1.65 & $\ldots$ \\
\hline 3. Asia & $1972-9$ & 0.21 & 0.32 & 0.21 & $\ldots$ & 0.06 & 0.08 & 0.19 & 0.08 & \\
\hline $\begin{array}{l}\text { 4. Latin } \\
\text { America }\end{array}$ & $1972-9$ & 0.41 & 1.04 & 0.18 & & 0.19 & 0.19 & 0.43 & 0.60 & \\
\hline
\end{tabular}

\begin{tabular}{lcccccccccccc}
\hline Region/zone & Date & \multicolumn{1}{c}{ Soybeans } & Cotton & Coffee & Cocoa & Sugar & Vegetables & Beef & Pork & Poultry All \\
\hline 1. All LDCs & $1971-2^{1}$ & $\ldots$ & $\ldots$ & $\ldots$ & $\ldots$ & 0.50 & $\ldots$ & $\ldots$ & $\ldots$ & $\ldots$ & 0.88 \\
2. Africa & $1972-9$ & 23.59 & 0.23 & 3.12 & 1.57 & 1.06 & 1.13 & 1.82 & 2.56 & 1.99 & $\ldots$ \\
3. Asia & $1972-9$ & 2.33 & 0.17 & 1.25 & 14.17 & 0.13 & 0.41 & 0.65 & 0.39 & 0.32 & $\ldots$ \\
$\begin{array}{l}\text { 4. Latin } \\
\text { America }\end{array}$ & $1972-9$ & 0.68 & 0.23 & & 1.57 & 0.48 & 1.13 & 0.67 & 0.60 & 1.12 & $\ldots$ \\
\hline
\end{tabular}

Sources: Row 1 and fns. a: York, Miller, Dalrymple et al. 1977:51-2. Rows 2-4: Judd, Boyce and Evenson 1983:24-5.

Notes: ${ }^{1} 1972$ for LDC output, 1971 for research outlay by national centres. If we add research by CG centres ( 1976 data, reduced by $30 \%$ to allow very roughly for inflation), some figures increase, and become: rice, $.30 \%$, wheat, .70\%; maize, .81\%; sorghum, $.81 \%$; cassava, $.09 \%$; sweet potatoes, $.10 \%$; white potatoes, $.80 \%$; dry beans, $.32 \%$; chick peas, $.23 \%$, cattle, $.91 \%$.

${ }^{2}$ Dry beans in Row 1 (all LDCs).

politics are not only those of conventional state machines, but also of research. Scientists like to work on projects that appear interesting, internationally respected, paradigmatic and fashionable. Research directors structure incentives, advice, and moral suasion to advance such projects. AR is in most countries a foreign implantation. This not only increases - perhaps doubles - the cost of a scientist person-year directly, when the various housing, settlement, tax and other allowances to overseas experts are allowed for. Even more serious is the indirect effect in reducing the commitment of national scientists as they are denied national leadership roles. Such national AR scientists are induced to join the brain-drain out of research, often to lifelong work in many a Western institute or firm.

The process is hard to stop, because there are so many private gainers from the alienation and frustration of indigenous research. Both African and Western researchers gain cash and status. Western firms and institutes - even sometimes UN specialised agencies - generate demand for their own services and a case for 'aid' support from their own governments and universities. As for African governments and universities, the way for a department to gain prestige and cash is to initiate new research projects dependent on fresh foreign skills - "to grow a cabbage, call an expert from the FAO' - rather than to build on, or in many cases to rescue, old projects due for 'indigenisation' of leadership posts.

Are these words too harsh? I know that African food production will not respond significantly to current price-policy fashions, nor to tomorrow's fashions either, without seed-water-fertiliser-based research breakthroughs, tested for safety and profitability in smallholder environments. I accept, too - given 'twenty years largely wasted' in the post-Independence agricultures of many (not all) SSA countries - that such breakthroughs cannot be achieved without foreign involvement. But throwing money and foreign experts at half-analysed research issues, to create overlapping and (in all senses) foreign research systems, is not the way to achieve such research breakthroughs. 
Let us look again at two rather successful agricultural systems in the SSA context. In Kenya, 'out of a total of 390 research scientists engaged, less than 15 per cent have postgraduate or research-oriented training and qualifications that would fit them into the research and development functions to be performed'. In 1978, at $\mathrm{PhD}$ level, there were $15 \mathrm{Kenyans}$ in $\mathrm{AR}$ - and 27 non-Kenyans [Taylor et al. 1981:78, 129]. In Malawi, of 75 researchers, 'only four (excluding expatriates) have $\mathrm{PhD}$ degrees', and a further 21 'have sufficient training and experience to make them effective researchers if other essential resources were available' [Gilbert et al:: x, 21, 46]. Moreover, 'promotion opportunities . . . are insufficient to motivate researchers to stay in research' [ibid.: $\mathrm{x}]$.

\section{'Stratégies . . . elaborées par Paris'}

The problem in 'Francophone' SSA countries is much more serious. 'Cogestion' blends most of their research systems into dominant French institutions, methods, and even ministerial control. A multiplicity of cross-cutting, foreign-led research operations (plus, usually, a parallel but lower-status domestic operation) produces a mixture of neocolonialism and anarchy. Let us look at expert judgements before numbers, and again start with a relatively successful agricultural system, that of the Ivory Coast:

L'ensemble des institutions qui pratiquent des activités de recherche agronomique ... constitue un puzzle compliqué et imparfait, fruit de l'histoire du pays et d'initiatives plus ou moins opportunes. Un puzzle compliqué par le nombre et la nature des institutions concernées ... Un puzzle imparfait car toutes ces activités de recherche agronomique ne sont pas toujours complementaires ... Les [institutions] les plus importantes ....- plus de $80 \%$ des chercheurs ivoiriens [sont des] expatriés - ont été héritées de la colonisation et témoignent par leur fonctionnement, leurs ressources humaines, financières et materielles à l'omnipresence de la coopération française . . l'ORSTOM et les huit instituts GERDAT ont leur 'siège' en France et disposent, chacun, d'un 'réseau' constitué de centres et de laboratoires de recherche en France (metropole et Outre-Mer) . . . Ces neufs organisations ont eu jusqu'à présent des stratégies autonomes de coopération et de recherche, définies par leurs instances de direction (où sont representés les Ministères françaises concernés)... Les implantations en Côte d'Ivoire ... ont gagné, par la volonté ivoirienne, en autonomie par rapport aux stratégies scientifiques transnationales élaborées par Paris [von der Osten et al. 1982:15-167.

Gain in scientific autonomy is worth having, but why should a nation, with complex agricultural problems (and deteriorating performance), sacrifice anything of its research policy to 'stratégies scientifiques transnationales élaborées par Paris' (or London, Washington, Moscow, etc.)? Is not the result, in conjunction with the need to develop national AR institutions alongside the French-dominated ones - and the likelihood that the national institutions will offer lower pay and status - sure to be unsatisfactory?

Conflict, confusion, and lack of Ivoirien self-reliance are inherent in the system of research 'cogestion', ultimately dependent on 'stratégies ... élaborées par Paris'. The consequences go far beyond [ibid.: 44] "les multiples sinon excessives sollicitations extérieures (réunions, déplacements, visites)' - symptomatic of and contributory to, brain-drain as these doubtless are.

The resulting numbers, indeed, are staggering for a country independent for almost a quarter-century, and with one of SSA's better living-standards, literacy rates, and - until about 1975 - agricultural records. In 1981 , only 61 of 238 researchers - 31 of 178 in the 'instituts cogérés', 30 of 34 in the relatively tiny national system - were Ivoirien. Foreign dominance interlocked with high emphasis on research into export and industrial crops; of the 168 commodityassignable workers, these crops commanded 91, of whom 82 per cent were foreign, as against 54 for food-producing agriculture [ 68 per cent: ibid: : 18,26$]$. Financially, too, this is a foreign programme: in 1981, the Ivory Coast paid for only 38.8 per cent of 'its' public-sector AR [ibid.: 49].

The situation is probably even worse in similarly French-dominated AR systems in really poor - and much less literate, yet more agriculture-dependent countries of SSA. Burkina Faso is an interesting exception, in that 64 of its 123 AR scientists in 1982-83 were nationals; but this could be achieved only by incurring a cost per scientific person-year about double the levels prevailing in West Africa, and perhaps partly for that reason - by meeting 'plus de $90 \%$ de l'ensemble des dépenses, meme celles comprenant des allocations en paiement du personnel de la Fonction Publique . . par des sources de financement en provenance de l'etranger' [Antione et al. 1983: 33]. To permit significant indigenisation of research personnel - in a system where foreign institutions at once attract brain-drain and repel those seeking promotion to genuine leadership and control of national research - a very poor country must offer salaries implying financial alienation: Catch-22.

Many SSA governments rightly wish to avoid posthaste indigenisation at the expense of research quality. However, foreign-dominated research systems where expatriates come and go and bring prestige, 
cash, and draining prospects for national brains have at once severe developmental limitations, and built-in pressures: to maintain themselves; to research for Western journals, often at the cost of local relevance; to insert colleagues, and to export, rather than to promote, local talent. Given the long-term problems of most SSA educational systems, the only feasible solution to the immediate dilemma - that rapid indigenisation loses quality, but that slow indigenisation is infeasible given the above pressures - is to develop agricultural policy and AR systems that are less costly, in general and especially in terms of expatriate skill and money.

\section{Agricultural Policy, AR and Social Science}

Economics and other social sciences are most needed when the natural scientist appears most confident that they are not. For example, it is too easy for AR scientists to propose - and for visiting experts to confirm - that, 'abandoned tea fields suggest that the new small holders do not yet fully understand the risks and opportunities of intensive tea cultivation' [ibid: 36]. A micro-economist would first test whether the intensive advice might conflict with smallholders' preferences; a sociologist, whether the gains from intensive cultivation are not sought by the smallholder because they would be absorbed by, or would strengthen, actual or potential landlords or moneylenders; a planning or benefit/cost economist, whether major switches to tea production (given its effect on prices, plus likely exogenous price trends) are desirable for Kenya.

Without an agricultural policy, research organisation is not much use. A centralised organisation can mean further removal of researchers from both professional motivation and farm-level contacts, and further diversion of time from research, especially in the year or two while the new organisation (and its power struggles) are settling down. There is, unfortunately, more than a hint of faith in a centralised research blueprint, as at least a partial substitute for agricultural policy, about some of the recent reports on African national systems [e.g. Taylor et al. 1981: vii; Contant et al. 1982: 51, 67-8; Antoine et al. 1983: i-ii, v, 43].

Given that agricultural policy is likely to remain selfcontradictory, pressure-ridden and messy, can anything useful be said in general about AR? That its content can change cost-effectively - by crop-mix, via farm-level socioeconomics, etc. - we have illustrated. No great global verities about its form (more outstations for outreach, or fewer for critical mass?) are on offer.
Government willingness to spend more on AR depends, in part, on the perceived efficiency of such spending. Suppose, first, that 'efficiency' means contribution to net value added by farm output per unit of input, irrespective of distribution of that output, and assuming that we know the relative product and input prices at the time when the research comes onstream. The 'efficiency' of research can be increased either by lowering cost or by raising benefit. The resulting cost/benefit ratio is increased by delay - and subjected to risk - at each of three stages: (a) between initiation and successful output of the research, (b) between output and adoption by the farmer, (c) between adoption and attainment of higher ratios of farm output values to farm input values.

Good research design choices, e.g. of regions or crops (or crop-mixes, or livestock-crop combinations) for special emphasis, therefore do not depend only on the research director's best-estimate probability of a successful outcome, even as modified by an economist's best estimate of the rate and extent of adoption and diffusion, and the scientist's of the yield response to various levels and circumstances of adoption. They depend also on the delay at each stage - and on the degrees of confidence attached to each of those three estimates, from which we can calculate the probability-distributions of given increases in farm output in five, seven, ten . . years as a result of initiating the research.

In general, there is a trade-off between accepting different sorts of cost, delay, or uncertainty: in respect of achieving research success; of achieving $X$ per cent diffusion given success; of achieving the expectedvalue $Y$ per cent rise in yields given diffusion. Also there is a trade-off between quick results and certain results; and between speed and certainty, on the one hand, and cheapness on the other. These trade-offs carry research design implications: should one concentrate research on raising output in safer areas, on raising output of safer crops in risky areas, or on reducing risk to a given crop and area?

\section{Distributional Considerations}

So far, this discussion has largely omitted distributional considerations, for three reasons. First, intra-rural distribution in most of SSA is far less unequal than in South Asia. Second poor people's main hope in SSA is to reduce the grotesque rural-urban gaps. Third the overriding need for poor people is to get per-person food availability rising somehow in a set of environments where it has been falling. In SSA, unlike South Asia, most poor people are directly farming for food, so that, unless stupid tractorisation policies are adopted, higher availability will accompany higher power to purchase food. 
However, these points are not quite sufficient. HYVs' 'second-generation problems' arrive very fast, even in SSA, especially alongside growing labour gluts. For example, we are told that the Chilalo Agricultural Development Unit (CADU) in Ethiopia 'rapidly expanded use of improved varieties of wheat and teff and of fertiliser by farmers participating in the project, with an approximate doubling of wheat yields' [Anthony et al. 1979: 256]. Indeed so; but it also encouraged the dispossession of tenants by large landlords, who then displaced labour with combine harvesters. The view that - in Kenya, for instance - subsistence-commercial 'dualism is gradually being transformed with the division of large farms in the high-potential areas into smaller commercial farms and the formation of a continuum from subsistence farming to highly commercialised large-scale farming' [Taylor et al. 1981: 4] is much too sanguine. Political and economic factors, alongside rising person/land ratios, can induce polarisation; and, even if there is a transition from bimodal to unimodal agricultures as Taylor and his colleagues predict, the result need not be less unequal, or better for the poor, if the variability of farm size (or net income) around the mean is very high in the unimodal situation.

It is notable that although the current Kenyan Plan's 'basic strategy for development ... is the alleviation of poverty, throughout the nation', poverty-orientation played no part in the terms of reference for the report on its AR commissioned by the Government from ISNAR [Taylor et al. 1981: 1, 10; their italics]. Indeed, 'There was no convincing evidence that major emphasis is being placed on the development of production technologies for the small farmer' [ibid: : i, xii]. As we have illustrated, the relative weakness of food-crop research, especially for cheap calorie sources consumed locally, further militates against equal distribution, even relative to initial income, of AR benefits.

Probably, almost all the sorts of change that would be introduced into AR in SSA for reasons of dynamic efficiency - a shift to labour-intensity, to underresearched root crops and subsistence cereals, to riskreduction via controlled water supply - would tend to improve income distribution as well. The goal of reducing poverty, therefore, strengthens arguments for $A R$ reform that are strong already.

One possible exception concerns the regional balance of research. A research-station strategy to maximise expected net agricultural value added from given research inputs might mean further neglect of remote regions, and hence of many of the poor. If research stations need to avoid risk by going for some fairly safe 'winners' among their AR projects, then the initial researcher ignorance (and water risk) besetting many remote areas might, once again, direct $A R$ away from seeking to benefit poor people there. But the main threat to effective research for 'backward regions' is that they get opened up (by heavily-subsidised or 'free' transport and other grid-based infrastructures) to product competition - and emigration - before they have developed potential surpluses for specialisation and exchange.

National agricultural research in sub-Saharan Africa is, in general, not cost-effective. It concentrates heavily on a few export crops in price-inelastic demand, where, if it succeeds, the gains go largely to Western consumers. Poor people's crops - especially roots and cheap cereals, where on-farm or local consumption (plus hunger) mean that there is little or no problem about inelastic demand - are generally neglected. Unrewarding career structures mean rapid turnover, and this plus the large number of stations means generally below-critical scientific masses. Yet, for all the special problems of SSA's nu merous microclimates, a large accumulated reserve of internationally researched, largely seed-fertiliser-based, innovations is ready for national AR to undertake screening, testing, and adaptation to local smallholders' economic circumstances.

However, this will require policy change transcending AR. Reform of AR can help, though a centralised blueprint is not a panacea. However, a context in which SSA governments drastically raise the share of domestic cash and skill resources, current and capital, for the agricultural sector - including controlled water supply, especially micro-irrigation - is needed for major improvements from AR. These will do best, not 'only' for distribution but also on plain efficiency grounds, if they increasingly stress labour-intensity, smallholding, and roots and cheap cereals.

\section{References}

Anthony, K., B. Johnson, W. O. Jones and V. Uchendu, 1979, Agricultural Change in Tropical Africa, Cornell University

Antoine, P. (Chef de Mission), V. Aburca, G. Beye, N. Bosso, R. Devred, A. Green, F. LeBeau and I. Serejski, 1983, $L a$ Recherche Agronomique et Zootechnique: Haute Volta, World Bank/FAO/ISNAR, The Hague, March

Bond, M., 1983, 'Agricultural response to price in SSA countries', IMF Staff Papers, vol 30 no 4, December

Boyce, J. and R. Evenson, 1975, Agricultural Research and Extension Programs, Agricultural Development Council, New York

Carruthers, I. (ed), 1983, Aid for the Development of Irrigation, $\mathrm{OECD}$, Paris 
Cleaver, K., 1984, 'Impact of Price and Exchange-rate Policies on Agriculture in SSA', World Bank Staff Working Paper, Nairobi (draft)

Collinson, M., 1982, 'Farming Systems Research in Eastern Africa', International Development Paper No 3, Department of Agricultural Economy, Michigan State University

Contant, R. (Chef de Mission), K. Egger, R. Egli, M. Lasram, Z. Nyiira and G. Rocheteau, 1982, Le Ststème Nationale de Recherche Agricole au Rwanda, ISNAR, The Hague, December

Desai, G. and N. Namboodiri, 1983, 'The deceleration hypothesis and yield-increasing inputs in Indian agriculture', $I J A E$, vol 36 no 4, October-December

Evenson, R. and Y. Kislev, Agricultural Research and Productivity, Yale University Press

FAO, 1983, Production Yearbook 1981, Rome

Fell, A., 1983, 'An overview of irrigation strategy and results in the Sahel', in I. Carruthers (ed) op cit

Gilbert, E., et al., 1982, 'A review of the agricultural research system of Malawi', ISNAR, The Hague

Hayami, Y. and V. Ruttan, 1971, Agricultural Development: an International Perspective, Johns Hopkins, Baltimore

Heald, C. and M. Lipton, 1985, 'A frican Food Strategies and the EC's role: an Interin Review', Commissioned Study 6 , IDS, Sussex

IMF, 1983, Yearbook of Government Finance Statistics 1983, Washington, DC

Judd, A., J. Boyce and R. Evenson, 1983, 'Investing in Agricultural Supply', Discussion Paper no 442, Economic Growth Center, Yale University'

Lipton, M., 1977, Why Poor People Stay Poor, Temple Smith - 1984, 'Research and the Design of a Policy Frame for Agriculture', paper presented at OECD Development Centre/CERDI/IDS Conference on Rehabilitation and Recovery in SSA; forthcoming in Crisis and Recovery in sub-Saharan Africa: Realities and Complexities, OECD, Paris
-1985, 'The Place of Agricultural Research in the Development of sub-Saharan Africa', Discussion Paper 202, IDS, Sussex

Oram, P. and V. Bindlish, 1981, Resource Allocations to National Research Systems: Trends in the 1970s, ISNAR/ IFPRI, The Hague, November

-et al., 1979, Investment and Input Requirements for Accelerating Grow'th in Food Production in Low-income Countries by 1990, IFPRI, Washington, DC

von der Osten, A. (Chef de Mission), I. Arnon, A. Beenhakker, J. Casas, R. Contant, R. Devred and J. Martinez, 1982, La Recherche Agronomique en Côte d'Invoire, ISNAR, The Hague, October

Pinstrup-Andersen, P., 1982, Agricultural Research and Technology in Economic Development, Longman, Harlow

Rajpurohit, A., 1983, 'Recent trends in agricultural growth rates in Karnataka', I.JAE, vol 38 no 4, October-December

Sawant, S., 1983, 'Investigation of the hypothesis of deceleration in Indian agriculture', $I J A E$, vol 38 no 4 , October-December

Seers, D., 1983, 'Marxism and other neo-classical models', in The Political Economy of Nationalism, Oxford

Smith, J., G. Umali, M. Rosegrant and A. Mandac, 1983, Risk and Fertilizer Use on Rainfed Rice in Bicol, Philippines, Saturday Seminar, Agricultural Economics Department, IRRI, Los Banos, 15 October (mimeo)

Taylor, T. A. (Team Leader), M. Dagg, H. Kriesel, H. Messerschmidt, L. Roche, S. Muturi, F. Wang'ati and S. Chema, 1981, Kenya's National Agricultural Research System, ISNAR, The Hague, September

UN, 1983, Yearbook of National Accounts Statistics 1981, New York

World Bank, 1984, Toward Sustained Development in subSaharan Africa, Washington, DC

York, E., P. Miller, D. Dalrymple, O. Bjorkman, C. Kidd, H. Robinson, G. Beck, L. Hardin and L. Perinbaum, 1977 , Agricultural Research Organisation, Volume V (pt.2) of Supporting Papers to World Food and Nutrition Study, National Academy of Sciences for National Research Council, Washington, DC 